\title{
APLIKASI TANK MODEL DAN KESEIMBANGAN NERACA AIR STUDI KASUS MODEL DAS MIKRO (MDM),SUB-DAS CISAMPORA, DAS CIMANUK, KABUPATEN MAJALENGKA PROVINSI JAWA BARAT
}

\author{
Syampadzi Nurroh \\ Fakultas Ilmu Lingkungan Sekolah Pascasarjana \\ Universitas Gadjah Mada \\ Email:teknosains@ugm.ac.id \\ Nana Mulyana Arifjaya \\ Fakultas Kehutanan Institut Pertanian Bogor
}

\begin{abstract}
The influence of forest cover in landuse is an important concern in the goverment's regulation for distribution of water flow into the rivers. The River flow is one of the hydrology paramater importantness in order to be priority in managamenet environmental. The one of hydrology which could be used for water balancepredictionby Tank Model. The Tank Model was applied using daily rainfall, evapotranspiration, and discharge river. Based on research results that water balance are calculated by input parameter (precipitation, $678 \mathrm{~mm}$ ) with output parameter by discharge $(623,48 \mathrm{~mm})$ inequation curve discharge $\left(Q=1,606\left(T M A^{1,494}\right)\right)$ with the correlation $\left(R^{2}\right)$ is 0,993and evapotranspiration $(631,04 \mathrm{~mm})$. Based on the indicators of the reliability of the Tank model that the value of the correlation coefficient $(R)$ of 0,84 can be presented the results of verification in this case quite satisfactory. The water balancewas surplus ouput by calculated $550 \mathrm{~mm}$ of water storage in ground water $(38,80 \%)$, outflowdistributed recharge river $622,21 \mathrm{~mm}(33,90 \%)$ regard to runoff including $24 \%$ (runoff coefficient 0,24 ) and evapotranspiration $504,8 \mathrm{~mm}(27,30 \%)$.
\end{abstract}

Keywords: Tanks Model; Stream flow; and Water balance prediction

\begin{abstract}
ABSTRAK
Perencanaan dalam pengelolaan kawasan hulu suatu daerah aliran sungai (DAS) memiliki peran yang besar sebagai sistem perlindungan dan penyangga kehidupan sehingga keberadaannya perlu dikelola dengan baik agar peran tersebut tetap berfungsi secara lestari. Kawasan hulu ada yang memiliki tutupan hutan berpengaruh terhadap perubahan iklim dan air, pengaruh penutupan hutan menjadi perhatian penting dalam mengatur distribusi aliran air ke sungai-sungai. Oleh karena itu, informasi dan data tersebut dapat diperoleh dari proses keseimbangan neraca air, untuk memperoleh data dan informasi yang akurat maka diperlukan suatu penelitian. Penyajian data dan informasi terkait hubungan tutupan lahan eksisting dengan parameter hidrologi melalui keseimbangan neraca air. Proses verifikasi informasi dan data menggunakan aplikasi Tank Model. Berdsarkan hasil penelitian diperoleh bahwa 59,20\% tutupan lahan hutan di daerah penelitian menghasilkan keseimbangan neraca air, yaitupresipitasi $1678 \mathrm{~mm}(100 \%)$ terjadi surplus air sebesar $550 \mathrm{~mm}(38,80 \%)$ yang tersimpan dalam airtanah (storage water), debit aliran 622,21 mm/tahun (33,90), evapotranspirasi 504,8 mm/tahun $(27,30 \%)$.Total aliran terdistribusi pada surface flow sebesar $149,5 \mathrm{~mm}(24,03 \%)$, intermediate flow sebesar 320,3 mm (51,47\%), sub-base sebesar 47,2 mm (7,59\%) dan aliran dari base flow sebesar $105 \mathrm{~mm}$ (16,91\%). Debit aliran Surface flow menunjukan nilai koefisien runoff sebesar 0,24 yang termasuk kategori sedang dalam pengembangan wilayah.
\end{abstract}

Keywords: Debit aliran; keseimbangan neraca air; runoff dan Tank Model 


\section{PENGANTAR}

Perencanaan dalam pengelolaan kawasan hulu suatu daerah aliran sungai (DAS) memiliki peran yang besar sebagai sistem perlindungan dan penyangga kehidupan sehingga keberadaannya perlu dikelola dengan baik agar peran tersebut tetap berfungsi secara lestari. Kawasan hulu ada yang memiliki tutupan hutan berpengaruh terhadap perubahan iklim dan air, pengaruh penutupan hutan menjadi perhatian penting dalam mengatur distribusi aliran air ke sungai-sungai (Asdak 2007). Arsyad (2006) menyatakan bahwa tata air suatu DAS merupakan komponen penting dalam pengelolaan DAS karena kondisi hidrologis yang menjadi kawasan resapan air terutama di bagian hulu karena kerusakan di bagian hulu tidak hanya mempunyai efek yang bersifat on site tetapi juga dapat menyebabkan efek yang bersifat off site atau kerusakan di bagian hilir.

Perubahan penutupan lahan memberikan implikasi terhadap perubahan tata air di dalam suatu DAS. Sehingga, perlu informasi yang akurat tentang karakteristik hidrologi dengan parameter secara kuantitas dan kualitasnya. Salah satu teknologi yang dapat digunakan dalam memperoleh data tersebut adalah pembangunan SPAS (stasiun pengamatan arus sungai) dengan dilengkapi AWS (Automatic Weather Station) yang merupakan alat pemantau cuaca otomatis dengan basis data berupa data digital, sebagai salah satu model untuk menganalisis parameter tersebut dapat menggunakan Tank Model yang merupakan salah satu model yang dapat menggambarkan karakteristik hidrologi suatu wilayah DAS. Penerapan Tank Model diperlukan data harian berupa curah hujan, evapotranspirasi, dan data debit sungai (Setiawan 2003). Tujuan menganalisis keseimbangan neraca air dengan menggunakan aplikasi Tank Model untuk menggambarkan karakteristik hidrologi di Model DAS Mikro (MDM) Cisampora Sub-DAS Cimanuk, Kabupaten Majalengka, Provinsi Jawa Barat.
Artikel ini merupakan hasil dari riset yang dilaksanakan selama 5 bulan pada bulan Desember 2009 dan Januari, Februari, Maret serta April 2010 di Model DAS Mikro (MDM) Cisampora Sub-DAS Cimanuk Hulu, Kabupaten Majalengka, Provinsi Jawa Barat. Pemilihan alokasi waktu dalam penelitian dengan pertimbangkan musim penghujan di mana intensitas hujan terbesar berada pada bulan-bulan tersebut.

\section{Metode}

Daerah penelitian berada di Desa Lemah Putih, Kecamatan Lemahsugih, Kabupaten Majalengka, Propinsi Jawa Barat. Berikut ini disajikan pada Gambar 1. mengenai lokasi penelitian dan jenis penggunaan lahan pada tahun 2010. Letak koordinat posisis SPAS (statiun pengamatan arus sungai) di bawah pengelolaaan BPDAS Cimanuk-Citaduy yang secara administrasi terletak berada pada koordinat 700'43"LS, 108010'19" BT dan elevasi $950 \mathrm{mdpl}$.

Berdasarkan karakteristik morfometri sungai, Model DAS Mikro (MDM) Cisampora memiliki panjang sungai total $13,74 \mathrm{~km}$ dengan aliran terpanjang dari lokasi SPAS 6,49 km dan memiliki kerapatan sungai 3,18 $\mathrm{km} / \mathrm{km}^{2}$ Penutupan lahan di kawasan Model DAS Mikro (MDM) Cisampora Sub-DAS Cimanuk Hulu, bagian hulu didominasi oleh tutupan lahan hutan seluas 250,5 ha atau $59,20 \%$. Luas penutupan lahan pada kawasan Model DAS Mikro (MDM) Cisampora SubDAS Cimanuk Hulu dengan luas total 423,4 ha dapat dilihat pada Tabel 1.

Tabel 1

Penutupan lahan di Model DAS Mikro (MDM) Cisampora

\begin{tabular}{llll}
\hline No & Tutupan lahan & Luas (ha) & Luas (\%) \\
\hline 1 & Hutan & 250,5 & 59,20 \\
3 & Pemukiman & 11,40 & 2,70 \\
4 & Sawah Tadah Hujan & 75,80 & 17,90 \\
5 & Tegalan/ladang sayur & 85,70 & 20,20 \\
\hline & Total Luas & 423,40 & 100,00 \\
\hline
\end{tabular}

Sumber: BPDAS Cimanuk-Citanduy (2009) 


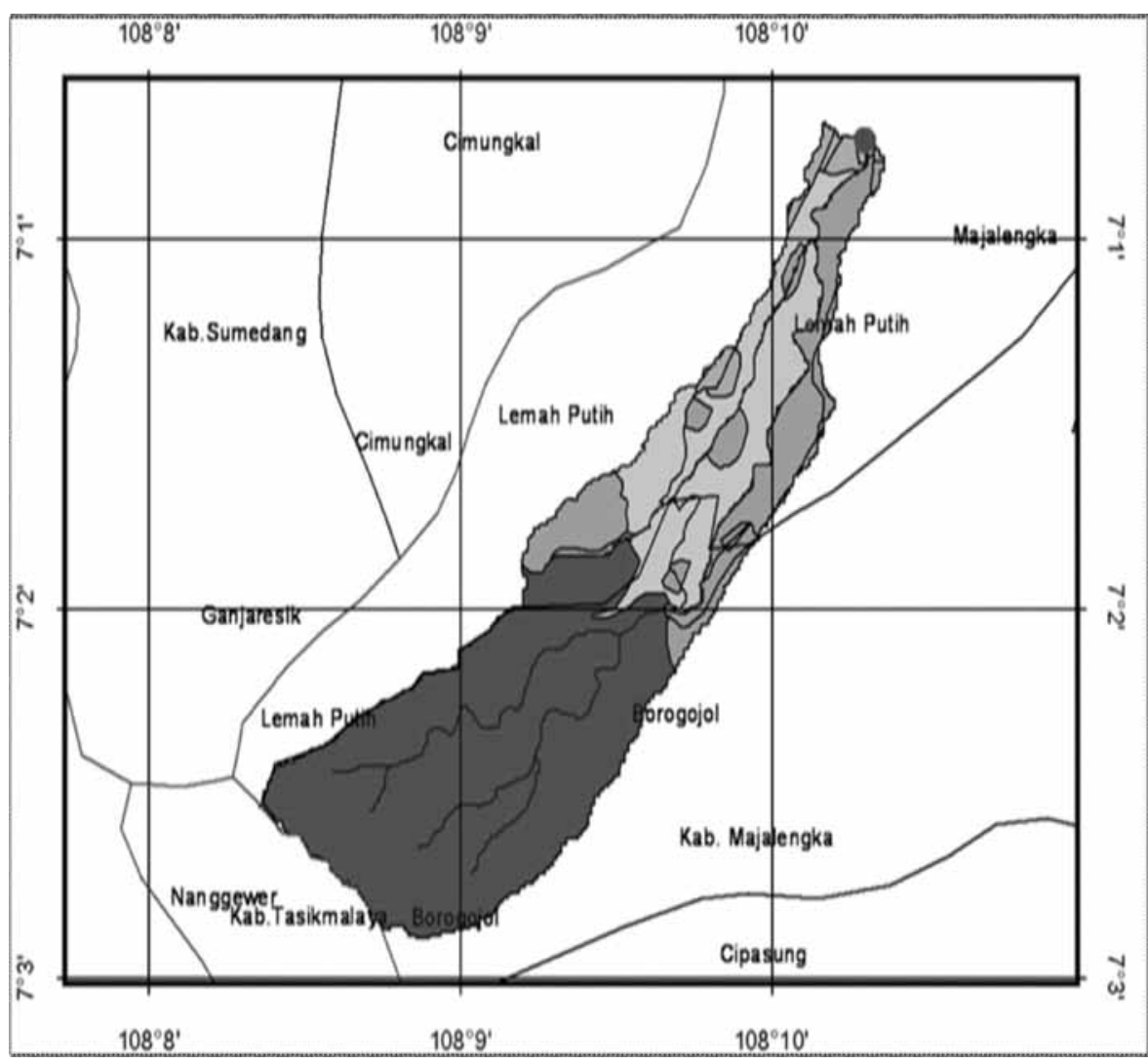

LEGENDA

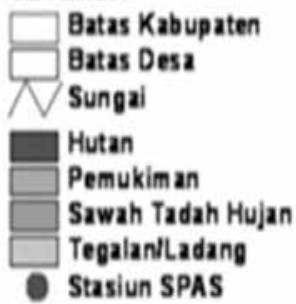

Gambar 1.

Peta lokasi penelitian dan jenis penggunaan lahan

Alat yang digunakan dalam penelitian ini disajikan pada Tabel 2. Seluruh alat terintegrasi dan terpasang pada logger sebagai penyimpan data digital di SPAS.

Tabel 2

Alat Digunakan dalam Penelitian

\begin{tabular}{llll}
\hline No & \multicolumn{1}{c}{ Nama Alat } & Tipe Alat & \multicolumn{1}{c}{ Fungsi Alat } \\
\hline 1 & Automatic Rainfall Recorder (ARR) & RG600 & Mengukur curah hujan air secara digital \\
2 & Currentmeter & FP101 & Mengukur kecepatan aliran air secara digital \\
3 & Bola pingpong dan Stopwatch & - & Mengukur kecepatan aliran air secara manual \\
4 & Automatic Weather Station (AWS) & - & Mengukur suhu, radiasi surya, dan RH secara digital \\
\hline
\end{tabular}

Sumber: BPDAS Cimanuk-Citanduy (2009)

Alat penakar curah hujan yang digunakan adalah penakar otomatis tipe ARR (automatic Rainfall recorder) yang dipasang di bagian hilir Sub-DAS. Tinggi muka air diukur dengan alat pencatat muka air otomatis (AWLR). Kecepatan arus sungai diukur dengan menggunakan alat pengukur arus (current meter).Pengukuran hujan dilakukan setiap hari (hujan harian), sedangkan tinggi muka air diukur setiap lima menit. Kecepatan aliran sungai diukur periodik untuk mendapatkan data kecepatan aliran pada keadaan tinggi muka air yang bervariasi.

Data input Tank Model yang terdiri dari presipitasi, debit aliran sungai dan evapotranspirasi. Debit aliran sungai menggunakan persamaan regresi $(Q=a$ $\left.T M A^{b}\right) \mathrm{m}^{3} /$ detik dikonversi menjadi satuan $\mathrm{mm} /$ hari dengan pendekatan tinggi muka air (Soewarno 1991); dan evapotranspirasi menggunakan model Penman-Monteith serta model tersebut cukup akurat digunakan di daerah tropis (Suprayogi dkk 2003) 
Analisis keseimbangan neraca air dihitung dari data presipitasi yang jatuh dalam suatu DAS, setelah diuapkan (evapotranpirasi) dan disimpan dalam bentuk air tanah (water yield) dan dialirkan ke sungai menjadi debit aliran sungai (Asdak 2007). Berikut ini bentuk umum persamaan water balance sebagai berikut:

$$
\mathrm{P}=\mathrm{Ea}+\mathrm{Q}+\Delta \mathrm{GS}
$$

\section{HASIL DAN PEMBAHASAN}

Penelitian bertujuan untuk menganalisis keseimbangan neraca air dengan menggunakan aplikasi Tank Model untuk menggambarkan karakteristik hidrologi. Penggunaan Tank Model sebagai proses verifikasi keseimbangan neraca air hasil observasi. Data input Tank Model yang terdiri dari curah hujan, debit aliran sungai, dan evapotranspirasi, data curah hujan dengan satuan $\mathrm{mm} /$ hari, debit aliran $\mathrm{mm} /$ hari, dan evapotranspirasi $\mathrm{mm} /$ hari.

\section{Analisis Data Input Tank Model}

\section{Analisis Data presipitasi}

Berdasarkan data sekunder atribut spasial MDM Cisampora terbagi menjadi dua klasifikasi B dan C dengan besaran nilai Q (tipe iklim) antara 14,30-33,33 \% atau sekurangkurangnya terdapat satu bulan kering dan tiga sampai tujuh bulan basah (BPDAS 2009). Data curah hujan bulanan saat penelitian termasuk bulan basah. Berikut fluktuasi curah hujan disajikan pada Gambar 2.

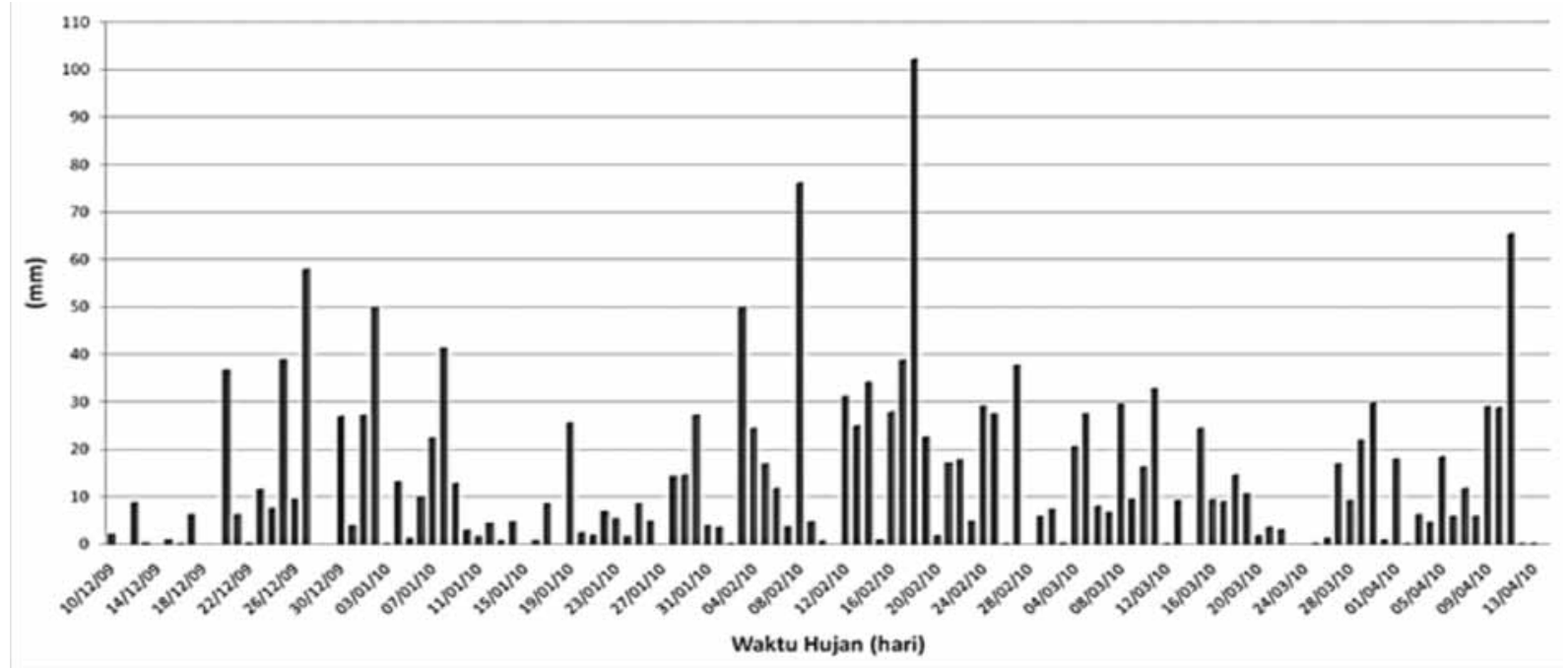

Gambar 2.

Fluktuasi Curah Hujan pada Desember 2009 - April 2010

Jumlah total curah hujan selama bulan Desember 2009 sampai April 2010 sebesar $1678 \mathrm{~mm}$. Curah hujan bulanan tertinggi di daerah tangkapan air (DTA) SPAS sebesar $611,8 \mathrm{~mm}$ pada bulan Februari dan terendah pada bulan April sebesar 194,8 mm. Kejadian hujan tertinggi terjadi pada tanggal 08 Februari dengan curah hujan 102,2 mm.

\section{Analisis Data Debit Aliran Sungai}

Hasil observasi lapangan berupa data debit aliran lapang dan tinggi muka air sebagai pendekatan perhitungan debit aliran, diperlukan pembuatan analisis regresi, dan korelasi untuk pembuatan kurva hubungan tinggi muka air dan debit aliran (stage discharger rating curve) (Chow et al1988; Soewarno 1991; Seyhan 1997). Berdasarkan persamaan regresi data hasil observasi diperoleh persamaan debit sebagai berikut:

$$
\mathrm{Q}=1,606\left(\mathrm{TMA}^{1,494}\right)
$$


Dengan hasil analisis nilai koefisien determinasi $\left(R^{2}\right)$ sebesar 0,993 di mana nilai ini menunjukan hubungan antara tinggi muka air lapang dan debit aliran lapang mempunyai hubungan dengan kategori sangat kuat.

Persamaan (2) digunakan untuk menghitung debit aliran harian dengan meng- gunakan data tinggi muka air hasil pengukuran alat yang disimpan di logger. Berikut ini Gambar 3 mengenai fluktuasi hubungan debit aliran dengan besarnya curah hujan dengan satuan debit dikonversi dari $\left(\mathrm{m}^{3} /\right.$ detik) menjadi mm.

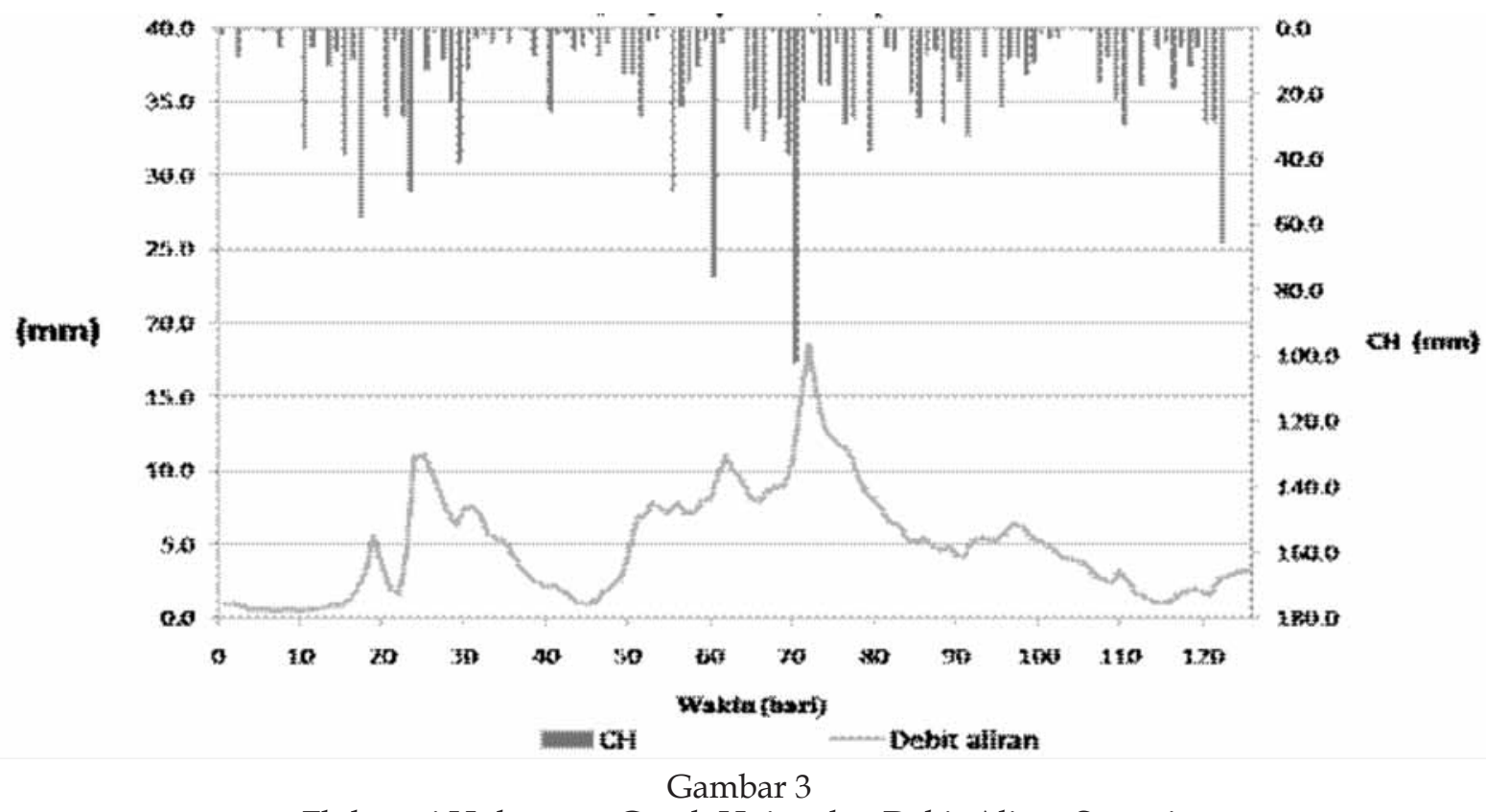

Fluktuasi Hubungan Curah Hujan dan Debit Aliran Sungai

Analisis hasil observasi lapangan dengan menggunakan persamaan regresi dalam menentukan debit aliran harian. Hasil yang diperoleh dari debit aliran di MDM Cisampora yaitu besarnya debit aliran total sebesar $624 \mathrm{~mm}$ dengan debit aliran terbesar pada bulan Februari sebesar 274,01 mm/ bulan dengan curah hujan sebesar 611,8 $\mathrm{mm} /$ bulan sedangkan yang terkecil pada bulan April sebesar 27,68 mm/bulan dengan curah hujan 194,8 mm/bulan. Debit aliran yang terjadi berdasarkan rata-rata bulanan sebesar 124,7 mm/bulan dan rata-rata debit aliran harian sebesar 4,24 mm/hari.

\section{Analisis Data Evapotranspirasi}

Hasil analisis pengolahan data evapotranspirasi diperoleh total evapotranspirasi sebesar $631 \mathrm{~mm}$, Berikut ini disajikan pada Tabel3 mengenai jumlah total bulanan dan harian evapotranspirasi.

Tabel 3

Data Harian Evapotranspirasi MDM Cisampora

\begin{tabular}{l|lcccc}
\hline Bulan $(\mathbf{m m})$ & \multicolumn{1}{c}{ Desember 2009 } & Januari 2010 & Februari 2010 & Maret 2010 & April 2010 \\
\hline Total & 111.86 & 157.69 & 136.2 & 157.3 & 67.99 \\
\hline
\end{tabular}

Sumber: Hasil Analisis, 2010

Berdasarkan data rata-rata evapotranspirasi harian masing-masing dari bulan Desember sampai April berturut-turut sebesar
5,08 mm/hari 5,087 mm/hari, 4,86 mm/hari, $5,07 \mathrm{~mm} /$ hari dan $4,86 \mathrm{~mm} /$ hari dengan ratarata harian evapotranspirasi sebesar 4,993 mm/ 
hari. Sedangkan besarnya evapotranspirasi pada setiap bulan berturut-turut sebesar 1118,86 mm; 157,69 mm; 136,2 mm; 157,3 mm; dan $67 \mathrm{~mm}$ dengan rata-rata evapotranspirasi bulanan sebesar $126,2 \mathrm{~mm} /$ bulan.

\section{Analisis Keseimbangan Neraca Air}

Keseimbangan neraca air dengan penggunaan persamaan (2) di atas yang terdiri dari curah hujan (1678 $\mathrm{mm})$, debit aliran sungai (624 mm), dan evapotranspirasi (631 mm). Berdasarkan perhitungan dari persamaan tersebut diperoleh cadangan airtanah total sebesar $423 \mathrm{~mm}$. Berikut ini disajikan Tabel 4 hasil rekapitulasi hasil observasi dan akan digunakan sebagai input Tank Model.

Tabel 4

Rekapitulasi Data Input Tank Model

\begin{tabular}{llllll}
\hline No & \multicolumn{1}{c}{ Data } & & Notasi & \multicolumn{1}{c}{$\begin{array}{c}\text { Jumlah Total } \\
(\mathbf{m m})\end{array}$} & Persentase $(\%)$ \\
\hline 1 & Curah Hujan & $\mathrm{P}$ & 1678 & 100 & 37 \\
2 & Debit Aliran Sungai & $\mathrm{Q}$ & 624 & 38 \\
3 & Evapotranspirasi & Ea & 631 & 25 & \\
4 & Storage water & $\Delta \mathrm{GS}$ & 423 & & \\
\hline
\end{tabular}

Sumber: Hasil Analisis, 2010

\section{Aplikasi Tank Model (Generic Algorithm Optimization)}

Keberhasilan model ditentukan oleh indikator Tank Model yang telah memenuhi kriteria keseimbangan air. Berikut ini disajikan pada Tabel 5 mengenai hasil indikator keandalan yang direprensentatifkan melalui koefisien korelasi dan koefisien determinan

Tabel 5

Indikator Keandalan Tank Model

\begin{tabular}{llll}
\hline No & Parameter Tank Model & Simbol & $\begin{array}{c}\text { Hasil } \\
\text { Optimasi }\end{array}$ \\
\hline 1 & Correlation Coefficient & $\mathrm{R}$ & 0,837 \\
2 & Determination Coefficient & $\mathrm{R}^{2}$ & 0,7 \\
\hline
\end{tabular}

Sumber: Hasil Analisis Tank Model, 2010

Berdasarkan indikator kebenaran dari keandalan Tank Model bahwa indikator kebenaran dilihat dari nilai (R) korelasi sebesar 0,84, hal ini dapat mempresentasikan kondisi lapang dengan baik antara perhitungan observasi dan kalkulasi, sedangkan koefisien determinasi $R^{2}(0,70)$ menunjukan verifikasi Tank Model dalam penelitian ini cukup memuaskan.Rudiyanto dan Setiawan (2003) menyatakan Tank Model memiliki standard yang terdiri 4 tank yang tersusun seri secara vertikal.

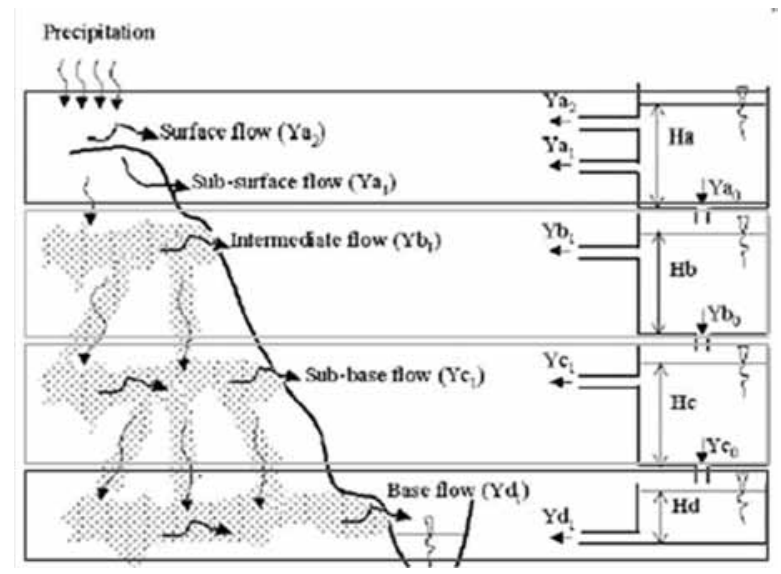

Gambar 4

Konsep Standard Tank Model

(Sumber: Rudiyanto dan Setiawan 2003)

Berdasarkan konsep tersebut, Setiawan (2003) menyatakan bahwa Tank Modeldapat mengasumsikan besarnya limpasan dan infiltrasi merupakan fungsi dari jumlah air yang tersimpan di dalam tanah. Berikut ini disajikan pada Tabel 6 mengenai hasil komponen optimasi dalam satuan $\mathrm{mm}$. 
Tabel 6

Rekapitulasi Hasil Komponen Optimasi Tank Model

\begin{tabular}{|c|c|c|c|}
\hline \multirow{2}{*}{ Komponen Tank Model } & \multirow{2}{*}{ Bagian Komponen } & \multicolumn{2}{|c|}{$\begin{array}{l}\text { Nilai } \\
\end{array}$} \\
\hline & & Satuan $(\mathrm{mm})$ & Persentase $(\%)$ \\
\hline \multirow[t]{5}{*}{ Keseimbangan air } & Inflow R (Presipitasi) & 1678 & \\
\hline & Outflow Calculation & 622 & 34 \\
\hline & Etp (Evapotranspiration) & 505 & 27 \\
\hline & Stored & 551 & 39 \\
\hline & Total & 1678 & 100 \\
\hline \multirow{4}{*}{$\begin{array}{l}\text { Tinggi Muka air setiap tank } \\
\text { (Water Level) }\end{array}$} & Tank A (Ha) & 59,260 & \\
\hline & Tank B (Hb) & 31,982 & \\
\hline & Tank C (Hc) & 778,791 & \\
\hline & Tank D (Hd) & 790,036 & \\
\hline \multirow{5}{*}{$\begin{array}{l}\text { Total Aliran } \\
\text { (Water Flow) }\end{array}$} & Surface flow & 149,524 & 24,03 \\
\hline & Intermediate Flow & 320,280 & 51,47 \\
\hline & Sub-Base Flow & 47,2072 & 7,59 \\
\hline & Base Flow & 105,197 & 16,91 \\
\hline & Total & 622,208 & 100 \\
\hline
\end{tabular}

Sumber: Hasil Analisis Tank Model, 2010

Hasil optimasi diperoleh keseimbangan air (water balance) disajikan pada Gambar 5dan data analisis pada Tabel 6 diperoleh total curah hujan $1678 \mathrm{~mm}$ dan debit aliran sebesar $622 \mathrm{~mm}(34 \%)$ serta evapotranspirasi dan cadangan airtanah masing-masing sebesar $505 \mathrm{~mm}$ (27\%) dan $551 \mathrm{~mm}$ (39\%).

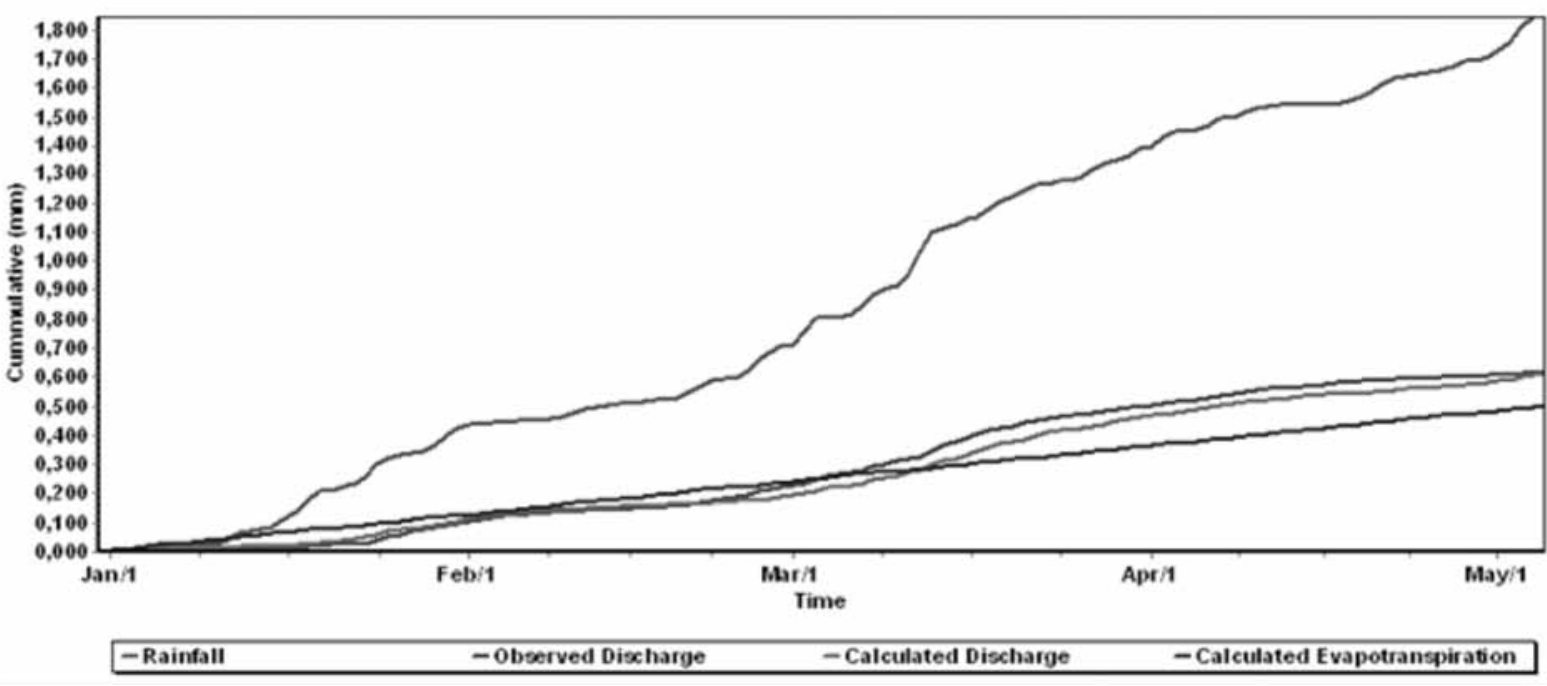

Gambar5

Keseimbangan Neraca Air Hasil Optimasi Tank Model

Hasil optimasi total aliran air (water flow) disajikan pada Gambar 6 diperoleh total aliran yang mengalir atau terdistribusi di surface flow, intermediate flow, sub-base flow dan base flow dengnan masing-masing nilai sebesar 149,52 $\mathrm{mm}(24,03 \%) ; 320,28 \mathrm{~mm}$ (51,47\%); 47,20 mm (7,59\%), dan 150,20 mm $(16,91 \%)$. 


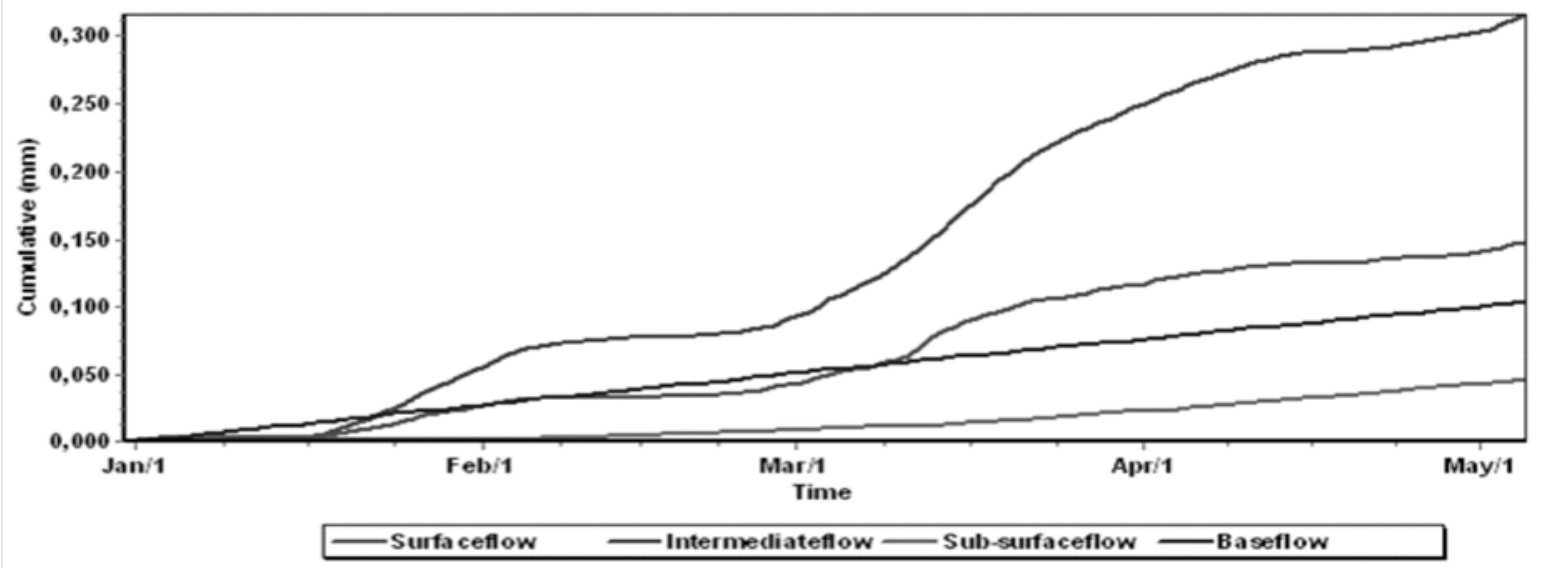

Gambar 6

Keseimbangan Total Aliran pada Setiap Water Flow

Total aliran hasil optimasi sebesar $622 \mathrm{~mm}$ dan total aliran yang mengalir ke sungai terbesar dari bagian intermediate flow $(51,47 \%)$, hal ini menunjukan bahwa terjadinya proses perlokasi dimana kapasitas infiltrasi cukup tinggi. Air dapat meresap ke dalam tanah terlebih dahulu sebelum menjadi aliran debit yang masuk ke sungai. Total aliran surface flow sebesar 149,52 mm $(24,03 \%)$, hal ini menunjukan besaran koefisien limpasan (runoff) di mana air hujan menjadi aliran permukaan. Koefisien aliran daerah perdesaan rata-rata $10-15 \%$, sedangkan daerah perkotaan antara 7090\% (Weert 1994 dalam Muta'ali 2012).
Berdasarkan nilai koefisien runoff terebut masuk dalam kategori Sedang (21\%-30\%) dengan pengembangan wilayah yang terbatas dan dikendalikan khususnya untuk permukiman dan jenis budidaya pertanian (Muta'ali 2012). Total aliran surface flow ini pada bulan penghujan (Desember-April), jika dihitung selama satu tahun periode maka koefisien runoff akan lebih kecil dari nilai sekarang berkisar antara 10\%-20\% yang berarti nilai tersebut masih dalam rata-rata niali koefisien runoff perdesaan. Berikut ini disajikan pada Gambar7 perbandingan perhitungan debit aliran hasil observasi dan kalkulasi Tank Model dengan selisih $2 \mathrm{~mm}$.

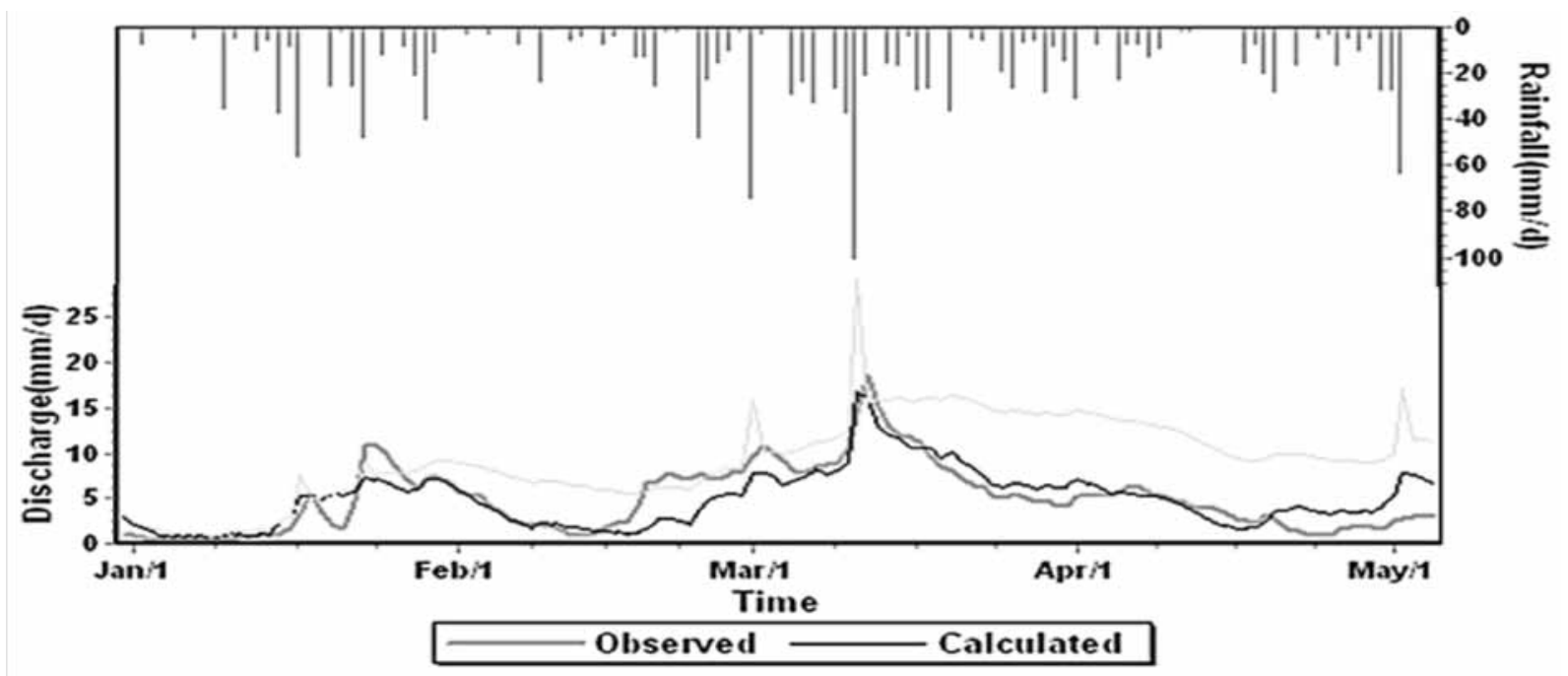

Gambar7

Hasil Debit Aliran Observasi dan Kalkulasi Tank Model 


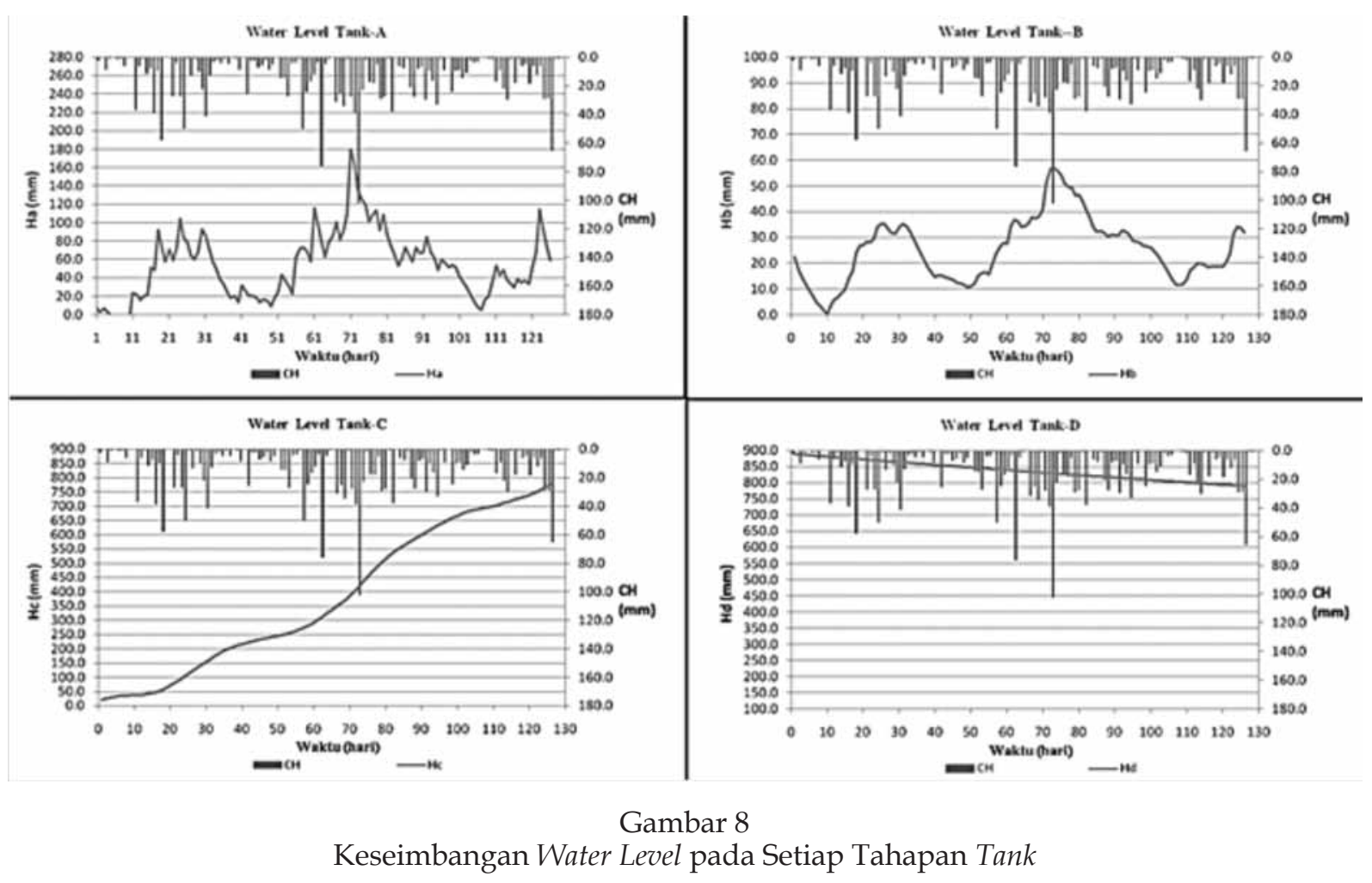

Berdasarkan hubungan (inflow) curah hujan $(\mathrm{mm})$ dan ketinggian dalam setiap level air yang mengalir secara vertikal hasil dari optimasi Tank Model, dapat menjelaskan bahwa curah hujan berpengaruh nyata terhadap perubahan keragaman tinggi aliran, karena adanya peningkatan dan penurunan curah hujan. Pengaruh curah hujan berbedabeda pada setiap level tank, pada level tank A $(59,3 \mathrm{~mm})$ surface flow sangat dipengaruhi secara langsung oleh curah hujan, ketika hujan tinggi maka akan diikuti dengan meningkatnya ketinggian air di surface flow.

Sedangkan pada level air di tengki B $(31,9 \mathrm{~mm})$ intermediate flow tetap dipengaruhi oleh curah hujan, tetapi tidak signifikan bila dibandingkan dengan surface flow. Pada saat memasuki level air di tengki C (778 mm) SubBase flow respon pengaruh curah hujan tidak langsung terjadi secara signifikan, tetapi mengalami peningkatan secara kontinyu ketika terjadi peningkatan curah hujan hingga pada level air di tank D (790 mm)
Base flow tersimpan dalam air tanah (storage). Hasil optimasi level air pada masing-masing tank dapat menjelaskan jumlah air terbesar selama bulan Desember 2009 sampai April 2010 adalah sebagai base flow sebesar $790 \mathrm{~mm}$.

\section{Analisis Keseimbangan Neraca Air di MDM Cisampora}

Berdasarkan sumber peta digital atribut penggunaan lahan DTA SPAS Cisampora sebesar 423,4 ha yang terdiri dari 250,5 ha hutan, pemukiman 11,4 ha, sawah tadah hujan 75,8 ha dan tegalan/ladang 85,7 ha (BPDAS 2009). Adanya tutupan lahan tegakan pohon karena hutan berfungsi sebagai daerah resapan air.Indikasi dari berfungsinya hutan sebagai daerah resapan air. Neraca air merupakan fungsi curah hujan dari hasil penjumlahan evapotranspirasi, debit aliran dan perubahan kadar air tanah. Berikut ini disajikan pada Tabel 6 mengenai neraca air hasil optimasi Tank Model dan Gambar 9 mengenai ilustrasi keseimbangan neraca air 
SYAMPADZI NURROH DAN NANA MULYANA ARIFJAYA $\$$ APLIKASI TANK MODEL DAN KESEIMBANGAN NERACA AIR STUDI KASUS MODEL DAS MIKRO (MDM), SUB-DAS ...

Tabel 6

Keseimbangan Neraca Air Hasil Optimasi Tank Model

\begin{tabular}{llllll}
\hline \multirow{2}{*}{ Bulan } & Tahun & \multicolumn{1}{c}{$\begin{array}{c}\text { Curah Hujan } \\
(\mathbf{m m})\end{array}$} & \multicolumn{1}{c}{$\begin{array}{c}\text { Debit Aliran } \\
(\mathbf{m m})\end{array}$} & $\begin{array}{c}\text { Evapotranspirasi } \\
(\mathbf{m m})\end{array}$ & $\begin{array}{c}\text { Perubahan Kadar Air } \\
\text { Tanah }(\mathbf{m m})\end{array}$ \\
\cline { 3 - 6 } & & $\mathrm{P}$ & $\mathrm{Q}$ & Etp & GS \\
\hline Desember & 2009 & 219 & 50,33 & 89,49 & 79,18 \\
Januari & 2010 & 320.4 & 118,48 & 126,15 & 75,77 \\
Februari & 2010 & 611.8 & 235,24 & 108,93 & 267,63 \\
Maret & 2010 & 332 & 149,63 & 125,84 & 56,54 \\
April & 2010 & 194.8 & 67,17 & 54,39 & 73,24 \\
\hline Total & & 1678 & 622,21 & 504,80 & 550,99 \\
\hline
\end{tabular}

Sumber: hasil analisis, 2010

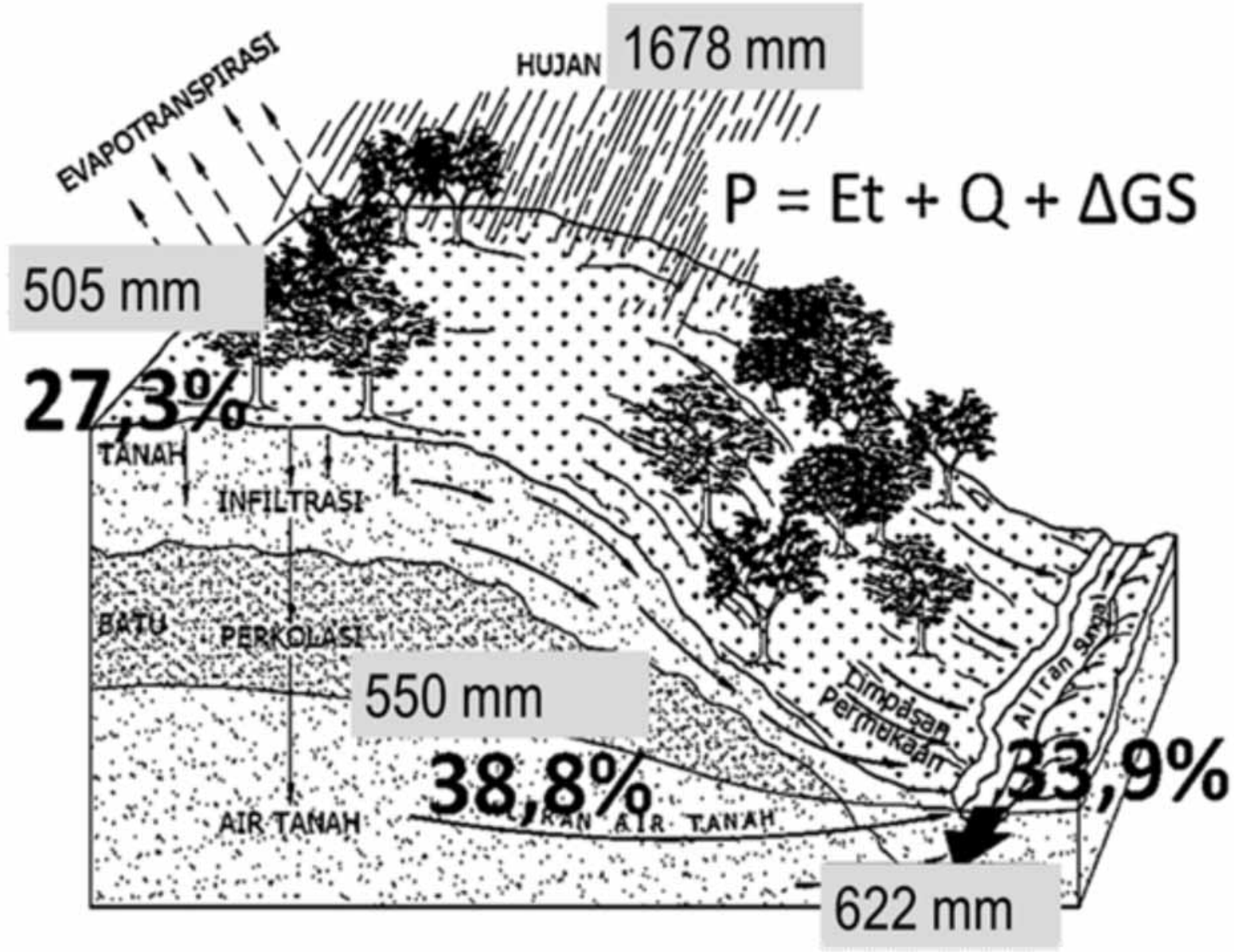

Gambar 9

Keseimbangan Neraca Air di MDM Cisampora

Chow et al (1988) menyatakan bahwa pembagian sub-sub DAS menjadi penting untuk pemodelan dalam pengembangan dan pengelolaan sumberdaya air. Berdasarkan konsep tersebut yang dihubungkan dengan hasil optimasi Tank Model dengan jumlah curah hujan sebesar $1845 \mathrm{~mm} /$ tahun, debit aliran 622,21 mm/tahun $(33,90)$, evapotranspirasi $504,8 \mathrm{~mm} /$ tahun $(27,30 \%)$ dan kadar air tanah sebesar $550 \mathrm{~mm}(38,80 \%)$. Debit aliran yang mengalir secara horizontal sebesar 622,21 $\mathrm{mm}$ yang mengalir yang terdiri dari surface flow $149,5 \mathrm{~mm}$, intermediate flow 320,3 mm, sub-base 47,2 $\mathrm{mm}$, dan base 
flow $105 \mathrm{~mm}$. Sehingga dengan aliran terbesar pada bagian intermediate flow dapat menunjukan kualitas tutupan lahan berupa hutan yang baik karena aliran air mampu terinfiltrasi ke dalam tanah sebelum menjadi aliran tanah secara horizontal ke sungai dan pengaruh terhadap kapasitas infiltrasi menjadi lebih besar sehingga mengurangi aliran permukaan (run off). Besarnya inflow berupa curah hujan (presipitasi) dan outflow berupa evapotranspirasi, total aliran, dan perubahan kadar air tanah (storage) tersebut dapat mempresentasikan keseimbangan air di MDM Cisampora Sub-DAS Cimanuk Hulu terjadi surplus air sebesar $550 \mathrm{~mm}$ yang tersimpan dalam air tanah.

\section{SIMPULAN}

Berdasarkan perumusan masalah dan batasan obyek maupun lingkup kajian penelitian yang didukung oleh konsep teori yang ada serta hasil analisis yang diperoleh dalam penelitian ini maka dapat disimpulkan sebagai berikut: pertama, kalibrasi perhitungan debit aliran dengan menggunakan persamaan regresi $(Q=1,606$ $\left(\mathrm{TMA}^{1,494}\right)$ ) dan indikator keandalan Tank Model dengan nilai koefisien korelasi (R) sebesar 0,84 dan nilai koefisien determinasi $\left(R^{2}\right)$ sebesar 0,70 menunjukan hasil verifikasi Tank Model dalam penelitian ini cukup memuaskan dalam penentuan debit aliran observasi.

Kedua, Keseimbangan neraca air terjadi surplus air sebesar $550 \mathrm{~mm}$ (38,80\%) yang tersimpan dalam air tanah (storage), presipitasi $1678 \mathrm{~mm}(100 \%)$, debit aliran $622,21 \mathrm{~mm} /$ tahun $(33,90)$, evapotranspirasi $504,8 \mathrm{~mm} /$ tahun $(27,30 \%)$. Total aliran secara horizontal yang terdistribusi pada surface flow sebesar $149,5 \mathrm{~mm}(24,03 \%)$, intermediate flow sebesar $320,3 \mathrm{~mm}(51,47 \%)$, sub-base sebesar 47,2 mm (7,59\%) dan aliran dari base flow sebesar $105 \mathrm{~mm}$ (16,91\%).

Berdasarkan hasil analisis dan kesimpulan yang diperoleh dalam penilitian ini, maka peneliti memiliki saran terkait proses dan hasil penelitian sebagai berikut: Pertama, untuk mempertahankan dan meningkatkan kualitas daerah tangkapan air, luas hutan perlu dijaga dan dipertahankan. Kedua, perlu adanya monitoring berkala dalam menijauan perubahan tutupan lahan dengan pendekatan keseimbangan neraca air. Ketiga, perlu adanya intensif konservasi tanah dan air secara kearifan lokal.

\section{DAFTAR PUSTAKA}

Arsyad, S., 2006,Konservasi Tanah dan Air. Bogor : IPB Press.

Asdak, C., 2007,Hidrologi dan Pengelolaan Daerah Aliran Sungai. Yogyakarta: Gadjah Mada University Press.

Balai Pengelolaan Daerah Aliran Sungai Cimanuk-Citanduy, 2009, Laporan rancangan SPAS Cisampora SubDAS Cisampora. Bandung: BPDAS Cimanuk-Citanduy, Direktorat Jenderal Rehabilitasi Lahan dan Perhutanan Sosial, Departemen Kehutanan.

Chow, V.T., Maidment, D.R., and Mays, L.W.,1988,Handbooks of applied Hydrology. New York: McGraw Hill International Editions- Civil Engineering Series.

Muta'ali, L., 2012, Daya dukung lingkungan untuk perencanaan pengembangan wilayah. Yogyakarta: Gadjah Mada University Press.

Rudiyanto dan Setiawan, B.I., 2003,Prinsip dasar TankModel. Bogor:Departemen Teknik Pertanian, Fakultas Teknologi Pertanian, Institut Pertanian Bogor.

Setiawan, B.I., 2003, Optimasi Parameter Tank Model. Buletin Keteknikan Pertanian. Vol. 17 No. 1 Hal: 8-20. Institut Pertanian Bogor.

Seyhan, E., 1997,Dasar-dasar Hidrologi. Yogyakarta: Gadjah Mada University Press.

Suprayogi, S., Budi, I.S., dan Lilik, B.P., 2003, Penerapan Beberapa Model 
Evapotranspirasi Di Daerah Tropika, Buletin Keteknikan Pertanian, Vol. 17 No. 2, Hal 7-13. Institut Pertanian Bogor.

Sunarti, 2008,Pengelolaan DAS berbasis Bioregion(Suatu Alternatif Menuju Pengelolaan Berkelanjutan). Jakarta:
Direktorat Jenderal Rehabilitasi Lahan dan Perhutanan Sosial, Departemen Kehutanan.

Soewarno, 1991, Hidrologi: Pengukuran dan Penglohan Data Aliran Sungai (hidrometri). Bandung: Penerbit. Nova. 